\title{
EFFECT OF NITROGEN-FIXING BACTERIA ON GRAIN YIELD AND DEVELOPMENT OF FLOODED IRRIGATED RICE ${ }^{1}$
}

\author{
AMAURI NELSON BEUTLER ${ }^{2 *}$, GIOVANE MATIAS BURG ${ }^{2}$, EVANDRO ADEMIR DEAK $^{2}$, MARCELO RAUL \\ SCHMIDT $^{2}$, LEANDRO GALON ${ }^{3}$
}

\begin{abstract}
This study aimed at evaluating the effect of Azospirillum brasilense, a nitrogen-fixing bacterium, on flooded irrigated rice yield. Evaluations were carried out in a shaded nursery, with seedlings grown on an Alfisol. Were performed two sets of experiments. In the first, were carried out four experiments using the flooded rice cultivars INIA Olimar, Puitá Inta-CL, Br Irga 409 and Irga 424; these trials were set up as completely randomized design in a $5 \times 4$ factorial scheme, with four replications. Treatments consisted of five nitrogen rates $\left(0,40,80,120\right.$ and $\left.160 \mathrm{~kg} \mathrm{ha}^{-1}\right)$ and four levels of liquid inoculant $\mathrm{Ab}-\mathrm{V} 5$ and $\mathrm{Ab}-\mathrm{V} 6-A$. brasilense (0, 1, 2 and 4 times the manufacturer's recommendation) without seed treatment. In second set, were performed two experiments using the cultivars Puitá Inta-CL and Br Irga 409, arranged in the same design, but using a 4x2 factorial. In this set, treatments were composed of four levels of Ab-V5 and Ab-V6-A. brasilense liquid inoculant $\left(0,1,2\right.$ and 4 times the recommendation of $\left.100 \mathrm{~mL} \mathrm{ha}^{-1}\right)$, using rice seeds with and without insecticide and fungicide treatment. Shoot dry matter, number of panicles, and rice grain yield per pot were the assessed variables. The results showed that rice seed inoculation with $A$. brasilense had no effects on rice grain yield of the cultivars INIA Olimar, Puitá Inta-CL, Br Irga 409 and Irga 424.
\end{abstract}

Keywords: Azospirillum brasilense. Grain yield. Oryza sativa.

\section{BACTÉRIA FIXADORA DE NITROGÊNIO E PRODUTIVIDADE E DESENVOLVIMENTO DE ARROZ IRRIGADO POR INUNDAÇÃO}

\begin{abstract}
RESUMO - O uso de bactérias fixadoras de nitrogênio do gênero Azospirillum brasilense tem sido recomendado para gramíneas como milho, trigo e arroz, porém seus benefícios necessitam ser melhor estudados. O objetivo deste trabalho foi avaliar o efeito da bactéria fixadora de nitrogênio A. brasilense na produtividade de arroz irrigado por inundação. O experimento foi conduzido em viveiro agrícola revestido com sombrite, utilizando um Plintossolo Háplico. No primeiro conjunto de experimentos utilizaram-se as cultivares de arroz irrigado por inundação INIA Olimar, Puitá Inta-CL, Br Irga 409 e Irga 424, constituindo 4 experimentos em delineamento experimental inteiramente casualizado, em esquema fatorial $5 \times$, com quatro repetições. Os tratamentos foram constituídos por 5 doses de nitrogênio $\left(0,40,80,120\right.$ e $\left.160 \mathrm{~kg} \mathrm{ha}^{-1} \mathrm{de} \mathrm{N}\right)$, e 4 doses de inoculante líquido composto por bactérias $A$. brasilense cepas Ab-V5 e Ab-V6 (0, 1, 2 e 4 vezes a recomendação). No segundo conjunto de experimentos, com as cultivares Puitá Inta-CL e Br Irga 409, utilizouse o esquema fatorial 4 x 2. Quatro doses de A. brasilense cepas Ab-V5 e Ab-V6 (0, 1, 2 e 4 vezes a recomendação de $100 \mathrm{~mL} \mathrm{ha}^{-1}$ ), sem e com tratamento das sementes do arroz com inseticidas e fungicidas. Foram avaliados a massa da matéria seca da parte aérea, número de panículas e produtividade de grãos de arroz/vaso. A inoculação das sementes de arroz irrigado por inundação, cultivares INIA Olimar, Puitá Inta-CL, Br Irga 409 e Irga 424, com A. brasilense cepas Ab-V5 e Ab-V6 não aumenta a produtividade de grãos de arroz.
\end{abstract}

Palavras-chave: Azospirillum brasilense. rendimento de grãos. Oryza sativa.

\footnotetext{
${ }^{*}$ Corresponding author

${ }^{1}$ Received for publication in 04/29/2014; accepted in 01/11/2016.

${ }^{2}$ Universidade Federal do Pampa, Campus Itaqui, Itaqui, RS, Brazil; amaurib@yahoo.com.br, gio_burg@hotmail.com, evandro.deak@hotmail.com, marceloraulschmidt@hotmail.com.

${ }^{3}$ Universidade Federal da Fronteira Sul, Campus Erechim, Erechim, RS, Brazil; galon@uffs.edu.br.
} 


\section{INTRODUCTION}

The symbiosis between leguminous plants and nitrogen-fixing bacteria, so-called rhizobia, brings significant contributions for biological nitrogen fixation (HUNGRIA et al., 2007). This process is believed to meet part of the nitrogen demand of grasses and may be performed by bacteria of various genera such as Herbaspirillum, Burkholderia and Azospirillum, which have been isolated from plants like rice, wheat, corn and sorghum (HUNGRIA, 2011). These bacteria have diverse $\mathrm{N}$-fixing mechanisms in grasses, many of them are free-living organisms (OKON; LABANDERA-GONZALES, 1994), being bacteria and plants species-specific and strongly affected by the environment (nitrogen and oxygen availability, and presence of other microorganisms). Among the studied bacterial species, Azospirillum brasilense can be highlighted because of its outstanding performance when associated with grass plants, such as corn and wheat (HUNGIA et al., 2010; NOVAKOWISKI et al., 2011; PICCININ et al., 2013).

Even though inoculation with bacteria have brought significant results in grain yield of grasses, these outcomes are not very consistent due to the lack of further study (HUNGRIA et al., 2010; HUNGRIA, 2011; MENDES et al., 2011; MÜLLER et al., 2016). Yield substantial increases have been observed in corn and wheat crops with the use of certain $A$. brasilense bacterial strains (HUNGRIA et al., 2010; MÜLLER et al., 2016), which are commercial lineages registered by the Brazilian Department of Agriculture (HUNGRIA, 2011), being available for corn, wheat and rice.

The Azospirillum genre is widely spread and can be found at varied population densities depending on its interaction with the used cultivar and the environment. In flooded environments, as in flooded rice farming, these microaerophilic bacteria find a favorable environment, improving crop nutrition and development (SOUZA et al., 2000). These bacteria occur in rice fields colonizing roots and stems endophytically (SILVA et al., 2004). Once there is no formation of apparently specialized structures for $\mathrm{N}_{2}$ fixation (nodules), and these microorganisms might invade plant tissue through wounds, cracks caused by lateral root emergence, mechanical injuries, and stomata, spreading throughout the plant by sap vessels (REIS et al., 2006).

Different responses can be achieved by inoculating Azospirillum strains with wheat, rice, corn and sorghum, and average grain yield ranges between 5 to $30 \%$ (FERREIRA et al., 2003; HUNGRIA et al., 2010; MÜLLER et al., 2016). However, there are few studies in flooded rice fields, due to a limited number of strains tested with this crop and low availability of commercial inoculant. In producing regions from western Rio Grande do Sul state, in Brazil, rice seeds have been inoculated with bacteria since the 2011/ 2012 harvest season; however, it is still poorly understood and documented the interaction between inoculants and nitrogen fertilizer, rice cultivars, management systems, as well as further grain yield gains.

The objective of this study was evaluate the effect of inoculating $A$. brasilense, a nitrogen-fixing bacterium, on flooded irrigated rice development and grain yield.

\section{MATERIAL AND METHODS}

Were performed two sets of experiments, totaling six trials. They were carried out in a shaded nursery during the 2012/ 13 harvest season, in the city of Itaqui-RS, Brazil (29 $12^{\circ}$ ' $28^{\prime}$ ' South, $56^{\circ} 18^{\prime}$ 28" West and $64 \mathrm{~m}$ altitude), using an Alfisol (EMBRAPA, 2013). The soil was sampled within a depth of $0-20 \mathrm{~cm}$ and subsequently sieved through 4 $\mathrm{mm}$ mesh for flooded rice cultivation. According to chemical analysis, the soil characteristics were $\mathrm{pH}$ $\mathrm{H}_{2} \mathrm{O}=5.1 ; \mathrm{P}=12.6 \mathrm{mg} \mathrm{dm}^{-3} \mathrm{~K}=0.153 ; \mathrm{Ca}=2.7 ; \mathrm{Mg}=$ $0.7 ; \mathrm{Al}=0.6 \mathrm{cmol}_{\mathrm{c}} \mathrm{dm}^{-3} \mathrm{~V}=50 \% ; \mathrm{OM}=1.6 \%$. Soil liming was performed three months before sowing, as recommended by SOSBAI (2014).

In the first set of experiments, were conducted trials using four cultivars of flooded rice (INIA Olimar, Puitá Inta-CL, Br Irga 409 and Irga 424). For these, were applied a completely randomized design in a $5 \times 4$ factorial scheme, with four replicates in $7.5 \mathrm{~L}$ pots $(6 \mathrm{~L}$ soil/ pot). Treatments consisted of five nitrogen rates $\left(0,40,80,120\right.$ and $\left.160 \mathrm{~kg} \mathrm{ha}^{-1}\right)$ and four levels of liquid inoculant strains Ab-V5 and Ab-V6 - Azospirillum brasilense (0, 1, 2 and 4 times the manufacturer's recommendation - Masterfix). The recommendation for $\mathrm{N}$ application is $120 \mathrm{~kg} \mathrm{ha}^{-1}$ (SOSBAI, 2014); while for the inoculant is $100 \mathrm{~mL}$ $\mathrm{ha}^{-1}$, under a concentration of $2 \times 10^{8}$ colony forming units/ $\mathrm{mL}$. The manufacturer recommends this concentration of inoculant for corn and rice.

In the second set of experiments, were conducted trials using two flooded rice cultivars (Puitá Inta-CL and Br Irga 409). Both trials were performed in completely randomized design and a $4 \times 2$ factorial scheme, with four replicates. The treatments consisted of four levels of liquid inoculant strains Ab-V5 and Ab-V6 - A. brasilense (0, 1, 2 and 4 times the manufacturer's recommendation), and using treated and untreated seeds. Seeds were treated using the following insecticides Fipronil (Standak ${ }^{\circledR}$ $80 \mathrm{~mL} 100 \mathrm{~kg}^{-1}$ of seed) and Imidacloprid (Gaucho ${ }^{\circledR}$ $67 \mathrm{~mL} 100 \mathrm{~kg}^{-1}$ of seed), and the fungicides Carboxin + Thiram (Vitavax Thiram 200 SC $^{\circledR} 200$ $\mathrm{mL} 100 \mathrm{~kg}^{-1}$ of seed).

At sowing, fertilization was applied at a rate of $10 \mathrm{~kg} \mathrm{ha}^{-1} \mathrm{~N}, \quad 350 \mathrm{~kg}$ ha $^{-1} \mathrm{P}$ (triple superphosphate), and $300 \mathrm{~kg} \mathrm{ha}^{-1} \mathrm{~K}$ (potassium 
chloride). The $\mathrm{P}$ and $\mathrm{K}$ doses were five times the field recommendation; fertilizers were milled in Wiley mill and homogenized with all soil in pot. Seeds were inoculated with $A$. brasilense strains on October 17, 2012, and then allowed to shade dry for $15 \mathrm{~min}$, before being sown. Six seeds were sown by pot at a depth of $3 \mathrm{~cm}$. At 14 days after sowing (DAS), each pot were thinned, leaving two equally spaced plants. The first $50 \%$ of the total amount of $\mathrm{N}$ was top dressed at $20 \mathrm{DAS}$, when plants reached V3/ V4 stage (COUNCE et al., 2000). The next day, pots were filled with water up to $4 \mathrm{~cm}$ above soil surface, being kept constant until harvest. At panicle differentiation stage - R0 (40 DAS), the remaining $50 \%$ of $\mathrm{N}$ was applied as urea. After emergence and throughout cropping, pots' locations were exchanged every two times by week to provide similar light conditions for all plants (treatments and replications)

Harvest was carried in February of 2013, about 120 DAS, with a difference of few days among cultivars. Hereinafter, we evaluated shoot dry matter, panicle number and rice grain yields per pot.

The results were submitted to $F$ test (variance analysis) and the means compared by the Tukey test for qualitative factors; and for quantitative ones, data underwent regression analysis.

\section{RESULTS AND DISCUSSION}

Figure 1 shows that the cultivars INIA Olimar, Puitá Inta-CL, Br Irga 409 and Irga 424 showed similar results regarding shoot dry matter, panicle number and rice grain yield in response to $\mathrm{N}$ levels and strains of $A$. brasilense (Ab-V5 and AbV6).

For the four cultivars, all assessed variables increased up to the rate of $160 \mathrm{~kg} \mathrm{ha}^{-1} \mathrm{~N}$, and grain yield presented a quadratic increasing trend in the four cultivars (Figure 1A). This might have occurred by the low OM content in soil $(1.6 \%)$ and by the supply of proper amounts of $\mathrm{P}$ and $\mathrm{K}$, maximizing the production potential of the crop to utilize the applied N. According Genro Jr. et al. (2010), once high amounts of $\mathrm{P}, \mathrm{K}$ are supplied to rice crops, a maximum $\mathrm{N}$-use efficiency can be achieved in both irrigated and dry seeding systems, mainly under high technological level and suitable climatic conditions.

There was no interaction between $\mathrm{N}$ levels $(0$ to $160 \mathrm{~kg} \cdot \mathrm{ha}^{-1}$ ) and $A$. brasilense bacterial strains (Ab-V5 and Ab-V6). Therefore, none of the rice cultivars responded in production to any of the doses applied of $A$. brasilense strains (Figure 1B).

Grain production has not increased with inoculation. A possible incompatibility between strains and rice cultivars may have affected this response. Despite being found records at the Ministry of Agriculture, Livestock and Supply
(MAPA) for upland rice, wheat and corn, there is no specific record for flooded rice. In this context, Campos et al. (2003) reported that certain rice genotypes had different responses with respect to biological $\mathrm{N}_{2}$ fixation, and some of them have achieved positive responses. Similarly, Moura (2010), who evaluated BRS Primavera cultivar inoculated with $\mathrm{Ab}-\mathrm{V} 5$ and $\mathrm{Ab}-\mathrm{V} 6$ strains, did not observed any grain yield increase. Moreover, it is known that $A$. brasilense 'Sp245' enhanced root and shoot growth of rice seedlings for most upland rice cultivars (EMBRAPA, 2003). Furthermore, Herbaspirillum seropedicae are able to increase rice grain yield in up to $50 \%$, depending on the strain used (GUIMARÃES et al., 2003).

Similar results to these found in this study were reported by Campos et al. (2000) for inoculation with the commercial product Graminante ${ }^{\circledR}(A$. brasilense), which is recommended for corn. This inoculant did not promote any grain yield gains as well; and the authors attributed that to a lack of specificity of the bacteria with corn hybrids (CAMPOS et al., 2000).

According Roesch et al. (2007), the interaction between diazotrophs and corn hybrids to fix nitrogen or promote plant growth depend on many biotic and environmental factors, such as cultivar, soil microbial community and $\mathrm{N}$ availability. Following that principle, we provided $\mathrm{N}$ low and high doses to the soil; however, positive results on $A$. brasilense inoculation were not confirmed. This way, we can state that another factor, other than $\mathrm{N}$, was responsible for the lack of bacterial growth and rice yield gain. We suggest that an absence of symbiosis between rice cultivars and A. brasilense strains $\mathrm{Ab}-\mathrm{V} 5$ and $\mathrm{Ab}-\mathrm{V} 6$.

Silva et al. (2004) and Cardoso et al. (2010) observed that Azospirillum spp. bacteria could develop at satisfactory densities in irrigated rice, under similar weather conditions, colonizing endophytically roots and stems. These authors also checked that soil chemical properties had no effect on the symbiont, except for $\mathrm{N}$ fertilizations that may reduce its population. Thus, the association can contribute to improve crop nutrition and growth (SOUZA et al., 2000). Therefore, it was shown that bacteria are of major importance to biological $\mathrm{N}_{2}$ fixation; though, further research is required to select strains with greater affinity for these rice cultivars, since Ab-V5 and Ab-V6 have not presented successful results.

Differently in wheat cropping, inoculations using these strains, $\mathrm{Ab}-\mathrm{V} 5$ and $\mathrm{Ab}-\mathrm{V} 6$, increased grain yield, increasing savings on $\mathrm{N}$ mineral fertilizers (HUNGRIA et al., 2010; PICCININ et al., 2013). In corn, there were also obtained grain yield increments using the strains $\mathrm{Ab}-\mathrm{V} 5$ and $\mathrm{Ab}-\mathrm{V} 6$ (HUNGRIA et al., 2010; BRACINI et al., 2012; MÜLLER et al., 2016). 

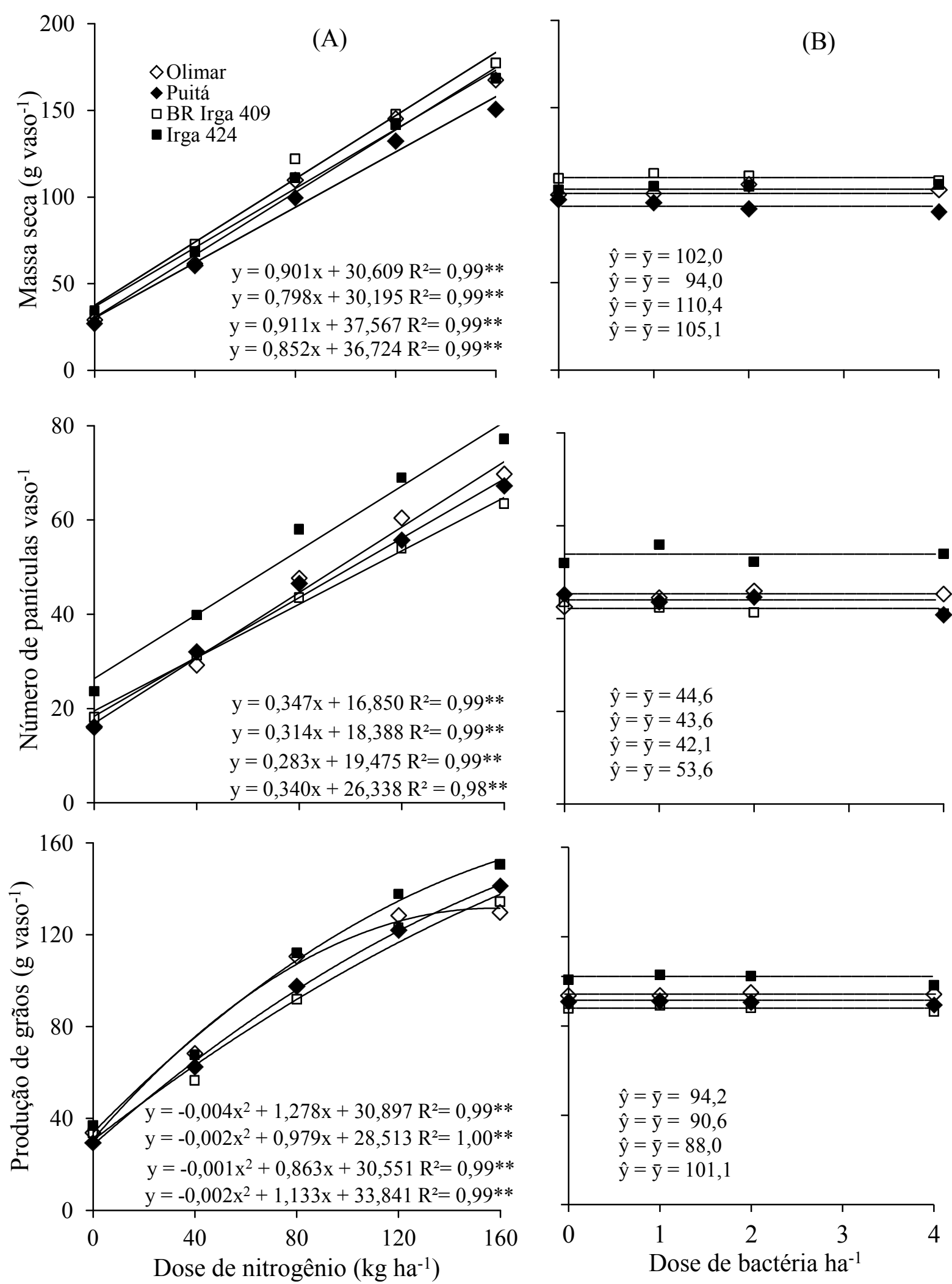

Figure 1. Mass of the dry matter of aerial part, number of panicle and flooded rice grain yield, cultivars Olimar, Puitá IntaCL, Br Irga 409 e Irga 424, in relation the $\mathrm{N}$ level (A) and A. brasilense level (B). ** Significant at 1\%.

Treating seed with insecticides and fungicides has not altered the response of rice cultivars to inoculation with the strains used, as can be seen in Tables 1 and 2, and Figure 2. Despite increasing dry matter and number of panicles, seed treatment did not increase grain yield for the cultivars Putiá Inta CL-i and Br IRGA 409. That fact is because treated seeds generate rice seedlings protected from insect and fungi infestations in the early crop cycle (SOSBAI, 2012). Nonetheless, this protection does 
not necessarily ensure increased yield, since other factors are involved in that variable, such as soil fertility, water supply, management system, besides temperature and sunlight conditions.

Therefore, A. brasilense strains Abv5 and Abv6 (Masterfix ${ }^{\circledR}$ ) had no effect on increasing yields of flooded rice, unlike what has been reported in other crops as wheat and corn (HUNGRIA, 2011; MÜLLER et al., 2016), for which the same commercial product is also recommended.

Table 1. Influence of bacteria Azospirillum brasilense in mass of the dry matter of aerial part, number of panicle and grain yield of flooded rice in cultivars Puitá Inta-CL e Br Irga 409, without N application, with seeds treated and not treated with insecticides and fungicides.

$\begin{array}{llll}\text { Treatment* } & \text { Dry mass }(\mathrm{g}) & \text { Number of panicle } & \text { Grain yield }\end{array}$

(g)

\section{Puitá Inta-CL}

Without seed treatment

With seed treatment

Without seed treatment

With seed treatment
$27.1 \mathrm{~b}$

$34.3 \mathrm{a}$
$16.2 \mathrm{~b}$

$20.9 \mathrm{a}$

$18.2 \mathrm{~b}$

$20.5 \mathrm{a}$
$29.5 \mathrm{a}$

Br Irga 409
$33.8 \mathrm{a}$

$33.6 \mathrm{a}$

Averages followed whit the same letter, in column and in the same cultivar, not differ at $5 \%$ of probability of error.

Table 2. Analysis of variance to flooded rice grain yield/pot, cultivars Puitá Inta-CL e Br Irga 409, whereas two experiments in randomized factorial scheme $4 \times 2$ (four levels of bacteria, whit and whitout seed treatment).

\begin{tabular}{|c|c|c|c|c|}
\hline Causes of variation & $\begin{array}{l}\text { Degree of } \\
\text { Freedom }\end{array}$ & Sum of squares & Medium Square & $\mathrm{F}$ \\
\hline \multicolumn{5}{|c|}{ Puitá Inta-CL } \\
\hline Factor A (bacteria) & 3 & 90.99 & 30.33 & $2.11^{\mathrm{ns}}$ \\
\hline Factor B (T.seed) & 1 & 57.67 & 57.67 & $4.02^{\mathrm{ns}}$ \\
\hline Factor A x B & 3 & 46.13 & 15.38 & $1.07^{\mathrm{ns}}$ \\
\hline \multicolumn{5}{|c|}{ Br Irga 409} \\
\hline Factor A (bacteria) & 3 & 59.81 & 19.94 & $1.09^{\mathrm{ns}}$ \\
\hline Factor B (T.seed) & 1 & 0.53 & 0.53 & $0.03^{\mathrm{ns}}$ \\
\hline Factor A x B & 3 & 149.61 & 49.87 & $2.73^{\mathrm{ns}}$ \\
\hline
\end{tabular}

${ }^{\mathrm{ns}}$ not significant. 


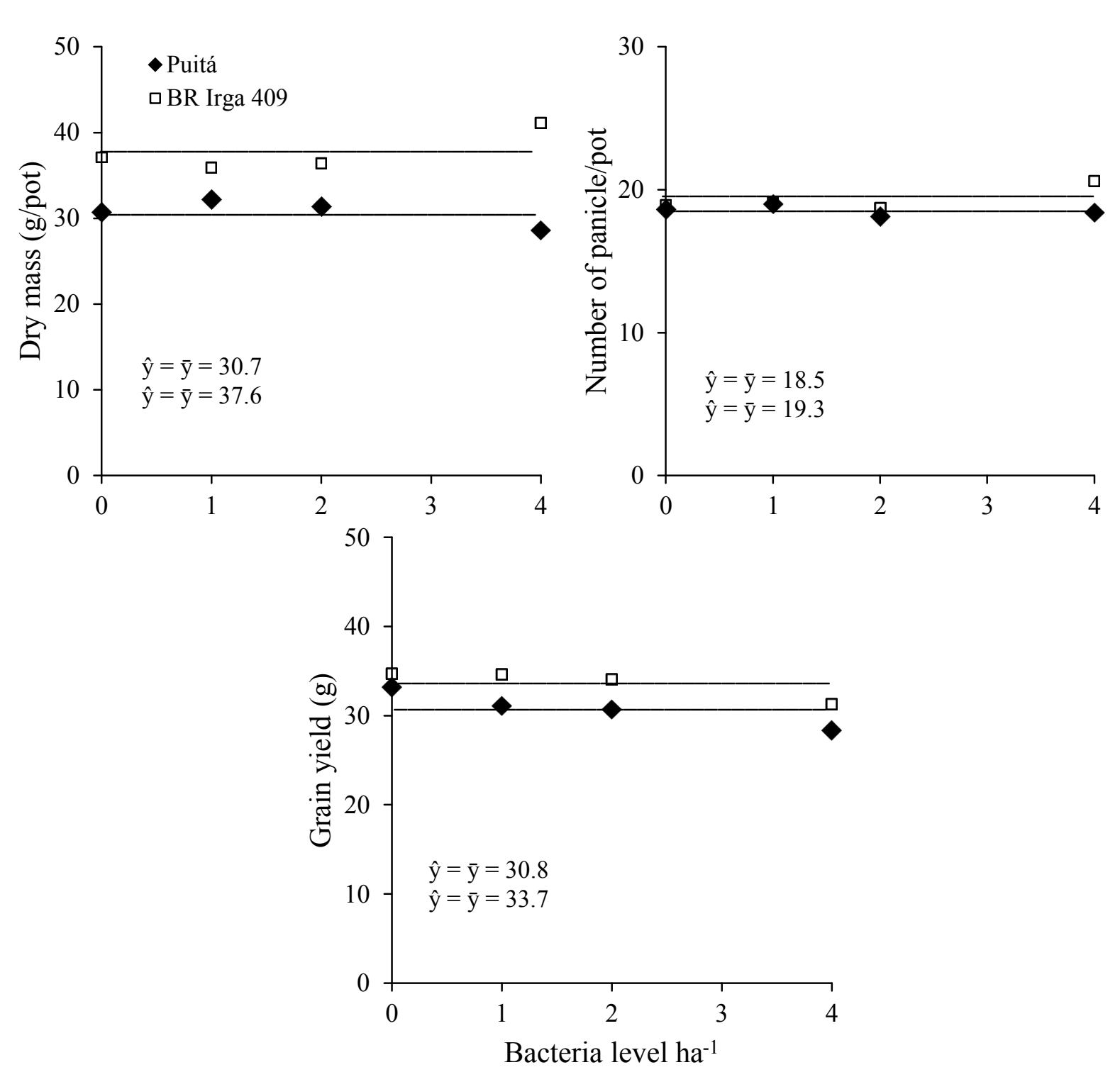

Figure 2. Mass of the dry matter of aerial part, number of panicle and flooded rice grain yield/pot (two plants), cultivars Puitá Inta-CL e Br Irga 409, in relatction of $A$. brasilense level In absence of mineral N.

\section{CONCLUSION}

Inoculation of the flooded irrigated rice cultivars INIA Olimar, Puitá Inta-CL, Br Irga 409 and Irga 424 with Azospirillum brasilense strains $\mathrm{Ab}$ -V5 and Ab-V6 (Masterfix ${ }^{\circledR}$ ) have no significant effect on rice crop yields.

Rice seeds treated with insecticide and fungicide (Fipronil and Imidacloprid, and Carboxin + Thiram) have no influence on the performance of both $A$. brasilense strains (Ab-V5 and $\mathrm{Ab}-\mathrm{V} 6)$ to increase shoot dry matter, panicle number, and rice grain yields.

\section{ACKNOWLEDGMENT}

The authors thank FAPERGS and CNPq by concessions of scholarships.

\section{REFERENCES}

BRACCINI, A. L. et al. Seed inoculation with Azospirillum brasilense, associated with the use of bioregulators in maize. Revista Caatinga, Mossoró, v. 25 , n. 2, p. 58-64, 2012.

CAMPOS, B. H. C. et al. Avaliação de inoculante Graminante na cultura do milho. Ciência Rural, Santa Maria, v. 30, n. 4, p. 713-715, 2000.

CAMPOS, D. V. B. de et al. Contribuição da fixação biológica de nitrogênio para a cultura de arroz sob inundação. Revista Agronomia, Seropédica, v. 37, n. 2, p. 41-46, 2003.

CARDOSO, I. C. M. et al. Ocorrência de bactérias endofíticas do gênero Azospirillum em arroz irrigado no estado de Santa Catarina. Revista de Ciências Agroveterinárias, Lages, v. 9, n. 2, p. 178-186, 
2010 .

COUNCE, P. A. et al. A Uniform and adaptative system for expressing rice development. Crop Science, Madison, v. 40, n. 2, p. 436-443, 2000.

DIDONET, A.D. et al. Avaliacão de linhagens de arroz de terras altas inoculadas com Azospirillum lipoferum Sp59b e A.brasilense Sp245. Santo Antonio de Goiás: Embrapa Arroz e Feijão, 2003. 4 p. (Comunicado Técnico 69).

SANTOS, H. G. et al. Sistema Brasileiro de Classificação de Solos. 3. ed. Rio de Janeiro: Embrapa, 2013. 353 p.

FERREIRA, J. S. et al. Seleção de veículos para inoculante com bactérias diazotróficas para arroz inundado. Revista Agronomia, Seropédica, v. 37, n. 2, p. 6-12, 2003.

GENRO JUNIOR, S. A. et al. Eficácia das recomendações de adubação para diferentes expectativas de produtividade de arroz irrigado por inundação. Revista Brasileira Ciência do Solo, Viçosa, v. 34, n. 5, p. 1667-1675, 2010.

GUIMARÃES, S. L. et al. Efeito da inoculação de bactérias diazotróficas endofíticas em arroz de sequeiro. Revista Agronomia, Seropédica, v. 37, n. 2, p. 25-30, 2003.

HUNGRIA, M. Inoculação com Azospirillum brasilense: inovação em rendimento a baixo custo. Londrina: Embrapa Soja, 2011. 36 p. (Documentos, $325)$.

HUNGRIA, M. et al. A importância do processo de fixação biológica do nitrogênio para a cultura da soja: componente essencial para a competitividade do produto brasileiro. Londrina: Embrapa Soja, 2007. 80 p. (Documentos, 283).

HUNGRIA, M. et al. Inoculation with selected strains of Azospirillum brasilense and A. lipoferum improves yields of maize and wheat in Brazil. Plant and Soil, Netherlands, v. 331, n. 1/2, p. 413-425, 2010.

MENDES, M. C. et al. Avaliação da eficiência agronômica de Azospirillum brasilense na cultura do trigo e os efeitos na qualidade de farinha. Revista Brasileira de Tecnologia Aplicada nas Ciências Agrárias, Guarapuava, v. 4, n. 3, p. 95-110, 2011.

MOURA, R. da S. Lâminas de água, inoculação de sementes com Azospirillum brasilense e doses de nitrogênio em arroz terras. 2010. 31 f. (Relatório) Universidade Estadual Paulista/Faculdade de Engenharia de Ilha Solteira, Ilha Solteira, 2010.
MÜLLER, T. M. et al. Combination of inoculation methods of Azospirilum brasilense with broadcasting of nitrogen fertilizer increases corn yield. Ciência Rural, Santa Maria, v. 46, n. 2, p. 210-215, 2016.

NOVAKOWISKI, J. H. et al. Efeito residual da adubação nitrogenada e inoculação de Azospirillum brasilense na cultura do milho. Semina: Ciências Agrárias, Londrina, v. 32, n. 1, p. 1687-1698, 2011.

OKON, Y.; LABANDERA-GONZALEZ, C. A. Agronomic applications of Azospirillum: an evaluation of 20 years worldwide field inoculation. Soil Biology \& Biochemistry, Oxford, v. 26, n. 12, p. 1591-1601, 1994.

PICCININ, G. G. et al. Efficiency of seed inoculation with Azospirillum brasilense on agronomic characteristics and yield of wheat. Industrial Crops and Products, Amsterdam, v. 43, n. 2, p. 393-397, 2013.

REIS, V. M. et al. Fixação biológica de nitrogênio simbiótica e associativa. In: FERNANDES, M. S. (Ed) Nutrição Mineral de Plantas. Viçosa: Sociedade Brasileira de Ciência do Solo, 2006. p. 153-174.

ROESCH, L. F. W. et al. Screening of diazotrophic bacteria Azopirillum spp. for nitrogen fixation and auxin production in multiple field sites in southern Brazil. World Journal of Microbiology Biotechnology, Dordrecht, v. 23, n. 10, p. 1377 $1383,2007$.

SILVA, D. M. da et al. Bactérias diazotróficas em solo cultivado com arroz irrigado (Oryza sativa L.). Revista Brasileira de Agrociência, Pelotas, v. 10, n. 4, p. 467-474, 2004.

SOSBAI. Arroz irrigado: recomendações técnicas da pesquisa para o Sul do Brasil. 1. ed. Santa Maria, RS: SOSBAI, 2014. 192 p.

SOUZA, R. O. et al. Solos alagados. In: Meurer, E. J. (Ed.). Fundamentos de química do solo. Porto Alegre: Genesis, 2000. cap. 7, p. 126-149. 